\title{
Efforts of NNCAE in Repositioning Adult and Non- Formal Education for Relevance in Nigeria: The Gender Perspective
}

\author{
Oluwatoyin Dorcas Ayimoro, Ph.D \\ Department of Adult Education, \\ Adekunle Ajasin University, Akungba-Akoko, Ondo State, Nigeria
}

doi: 10.19044/ejes.v4no2a5 URL:http://dx.doi.org/10.19044/ejes.v4no2a5

\begin{abstract}
Adult and Non-formal education provides the opportunities of responding to individual and societal needs through relevant training and education especially, as being challenged by constant technological change and novel knowledge. Adult Education is thus, problem solving. A major problem solving component of Adult Education is the potentials inherent in lifelong learning. The Nigerian National Council for Adult Education anchors both academic and practice of Adult Education in the nation initially, before a seeming decline in its activities. But since the split between the academic and practical practitioners had occurred, Adult Education had received a setback in its programmes. The question is, at a time of high level of inequality, unemployment and underemployment which may be connected with societal inhibitions and the skills received at various educational institutions of which women are the most vulnerable, what are the efforts of NNCAE in redeeming its professional ethics of providing the right education to the citizenry at a dire need? It is in response to these that this paper assesses and critiques the efforts of NNCAE in repositioning Adult and Non - formal Education for relevance in Nigeria.

This paper posits that NNCAE is capable of enhancing a better recognition for Adult Education discipline in Nigerian Universities through its "town gown" activities as it will educate the people on the need for gender equity and enhanced skills that could stem unemployment under employment and gender inequity in the society.
\end{abstract}

Keywords: NNCAE, Adult and Non - formal Education, Gender inequity, Unemployment and underemployment. 


\section{Introduction}

No doubt, Education is salient to the development of a nation. The Nigerian National Council of Adult Education is a major body providing Adult and Non -formal Education programmes and activities to the people of Nigeria. Adult and Non-formal education provides the opportunities of responding to individual and societal needs through relevant training and education especially, as being challenged by constant technological change and novel knowledge. Adult Education is thus, problem solving. A major problem solving component of Adult Education is the potentials inherent in lifelong learning that could assist in reducing inequality, unemployment and underemployment which result in weak democracy, poverty, crime and conflict as we can see today. These also pose a great threat on the stability and development of the nation where women are the most vulnerable.

There had been a shift from formal education and schooling to lifelong education because of its potential of being able to harness the potentials of the people better as it combines the formal, non-formal and informal patterns of education, continues throughout life and a guiding principle of universal education. Lifelong learning is indicative of growth, the understanding of oneself and the world. It breeds new skills and powers in discovering reality, being able to create things alone and in group for the renewal and development of the individual and the society.

Women have a profound and pervasive effect on their immediate families, communities, nation and world through the traditional roles they play as nutritionists in giving care and maintaining the health of the people which also have culminating effect on the environment. The Nigerian economy had so much implicated on the people that there had been increase and additional roles for women. Rather than augmenting the household income, majority of females have taken the roles of household heads irrespective of their level of education. Thus, female labour is salient in reducing inequality, poverty and underdevelopment in the society.

Women in developing economies, irrespective of their education are very creative, innovative and agents of change since time immemorial. They farm, produce food, manufacture products like soap, detergents, textiles, ornaments and engage in political processes when given the opportunity. However, majority are yet to reach the threshold of financial industrialists in their entrepreneurship engagement and impact maximally in decisionmaking in the society. According to Alese (2010, 2012, 2014 and 2016) women have not been able to maximize their potentials because of the non conducive environment, inequalities in the distribution of power and decision - making, the rigidity of status and distrust of new ideas, low technology and infrastructure, poor organization and the like in which women operate their 
chosen engagements. The problem solving nature of adult education could assist in solving these societal anomalies.

The NNCAE as an association came into being in 1971 through the effort of Governmental and Non-Governmental Organizations out of the need for the universalisation of access to education and the innovative movement for the survival of Adult Education both as a movement and an area of academic discipline in Nigeria involving University academics and Adult Education practionners as a brainchild of government and nongovernmental bodies. (NNCAE, Newsletter 1974 in Gidado, 2006). Adult and Non-formal Education activities had been in existence before 1971 but, these activities were neither recognized nor coordinated until the emergence of this body.

Although, the NNCAE ensured the inclusion of Adult and Nonformal Education programmes at various stages of the academic cycle which yielded positive results and gave a boost through financial support from the Federal government, State allocations and UNDP, the activities were not well spread to provide for major societal developmental inhibitions that could assist in reducing ills like inequality. Three university centers were designated to provide training for experts at various governmental and provisional levels which later spread to over fifteen institutions of higher learning and many Non-Governmental Organizations across the country by 1995 (NNCAE, 1995 in Gidado, 2006). These also brought the emergence of skilled Adult Education practitioners in Nigeria.

The NNCAE was later met with difficulties and it began to decline in its activities. Splinter groups arouse which threatened the international recognition as well as funding of the organization among others. ( NNCAE, 1995 in Gidado, 2006). Nonetheless, the council is picking up its pieces. Adult Education is multidisciplinary and a ready response in need time as this. In the face of the rising level of poverty, unemployment, underemployment, inequity, crime and insecurity among the citizenry where relevant education and training could be made to reduce such and where women potentials could thrive better through lifelong learning, this study sets to critique NNCAE's efforts in repositioning Adult and Non-formal Education for relevance in the nation.

\section{Literature Review}

\section{The Nigerian National Council of Adult Education}

The NNCAE was established on the $27^{\text {th }}$ March, 1971 at a conference of Adult Educators and Practitioners in Kano (NNCAE Newsletter, 1974 in Gadado, 2006). The main goal was to promote Adult Education and Community Development at National, State and Local levels in the Federal Republic of Nigeria. At inception it was a virile and growing organization 
involving university academics and adult education practitioners. That is, Governmental and Non-Governmental bodies (Gidado, 2006).

The NNCAE further had specific goals of:

- Promoting a means of communication for those interested in adult education;

- Representing the best interests of adult education in working with various levels of government;

- Promoting cooperation among adult education, community development and other agencies and the coordination of their programmes;

- Stimulating training programmes and the development of needed literature.

- Identifying problems on which research may be needed and to initiate and support such research projects; and

- Publishing an Adult Education journal to disseminate information and research throughout Nigeria and the world, (NNCAE, 1974:5).

Also, because there was neither order nor coordination of the activities of adult education before the birth of NNCAE, the founders believe in

- Making Adult Education an academic discipline that will compete favorably alongside other academic disciplines in the University;

- Encouraging government to support people to participate in Adult Education programmes as a discipline and a profession; and

- Making the discipline more refined and positioned as well as advocated at the various levels of government. (Gidado, 2006)

NNCAE achieved almost all the goals outlined within a span of time as it became a 'voice' for Adult Education discipline and practice in Nigeria. For instance, the NNCAE wrote a proposal for the National Adult Education programme for inclusion in the Third National Development Plan (1975 1980) which yielded positive results and favorable comments from Federal, States and UNESCO. Also, there was the establishment of departments and units of Adult Education in Universities, Federal Ministries of Education, State Agencies for Mass Education and units in Local Government Areas where specialists became directors (Gidado, 2006). Between 1970s and 1990s, adult educators emerged. There were special budgets for adult education at the University and government levels. Nigeria adult education was registered under UNESCO and African Adult Education Association (AALAE) emerged.

NNCAE facilitated the support of UNDP in Adult Education programmes in the 1950's. Journals and materials for the advancement of adult education were produced. The NNCAE was responsible for the inclusion of Adult and Non - formal Education in the Nigeria National 
Policy of Education (Gidado, 2006). NNCAE received annual subvention and grants from the Federal Ministries of Education. Her aggressive campaign led to a strong National Mass Literacy Campaign in 1980 with massive government support. (Gidado, 2006). Adult Education became deeply rooted in the academic and political landscape of Nigeria and the international community within twenty years. (Gidado, 2006). Over fifteen institution of higher learning and many Non - Governmental Organization run various adult education programmes and projects across the country as at 1995 (NNCAE, 1995 in Gidado, 2006).

However, the NNCAE met with challenges which led to its decline. It became more academic rather, than the initial flexibility nature of academic and practice. The academic members hijacked the affairs, this made the practitioners to take their leave and establish a rival association with the name Non - Governmental Association for Literacy Support Services (NOLGASS). There were accountability problems and accusations of mismanagement of resources, bad and closed - style of leadership, the international support for NOLGASS and crisis between the members of University of Ibadan that had been a leader in NNCAE activities. ABU Zaria discontinued its programmes (Gidado, 2006).It is equally sad to note that the NNCAE has not been registered with the Corporate Affairs Commission in Nigeria since inception.

\section{Adult and Non-formal Education}

Adult and Non-formal Education avails people the opportunities of responding to individual and societal needs through continuing education at any level and in various forms Eheazu (1998) asserts that:

The strongest and desirable role Adult

Education can and does play (is) in redressing

injustice, deprivations, and repression suffered

by victims of pseudo-egalitarianism and

insincerity of purpose in the provision made

for the general good in the education, training and

functional learning. Adult education is

therefore, a tool for resolving situational

problems in any given society.p3

Adult Education is conceptualised as an educational activity relatively planned and purposefully organised for people, irrespective of their age, location and socio-economic background, those who desire to learn in order to cope more satisfyingly with real life problems. (Nyerere, 2006 and Egunyomi, 2015).UNESCO further defines it as 
The entire body of organized educational process whatever the content, level and method, whether formal, or otherwise, whether they prolong or replace initial education in schools, colleges and Universities as well as in apprenticeship, whereby persons regarded as adults in the society to which they belong develop their abilities, enrich their knowledge, improve their technical or professional qualifications and bring about changes in their attitudes or behaviour in the two fold perspective of full personal development and participation in balanced and independent social, economic and cultural development.

Adult and non-formal education covers a variety of activities. It enhances peace, security of lives, civic participation, creativity, innovativeness, novelty, survival of the people and sustainable development. The scope of Adult Education is represented in the tree below. Egunyomi, 2015 p6

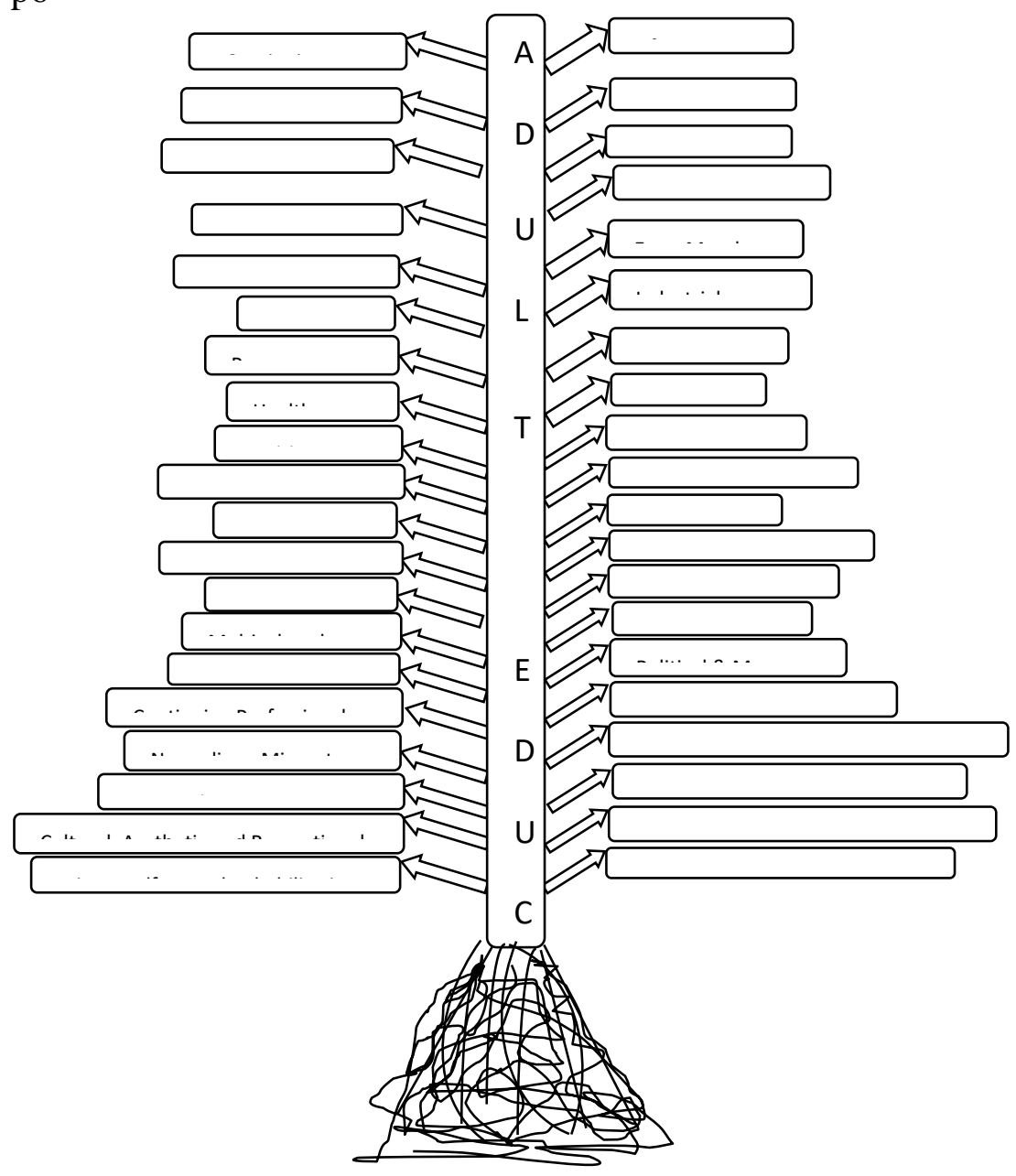


The salient characteristics of Adult Education are the richness, comprehensiveness, wideness, multidisciplinary and interdisciplinary scope. Perhaps the reason why it was re-conceptualised in Hamburg 1997 as:

The key to twenty-first century: Both a consequence of active citizenship and condition for full participation in society. A powerful concept for fostering sustainable development, for promoting democracy, justice, gender equity and scientific, social and economic development, and for building a world in which violent conflict is replaced by a dialogue and a culture of peace based on justice.... (Hamburg Declaration paragraph. 2)

According to Bhola (1979) Non-formal education covers all out-ofschool education programmes like agricultural extension and cooperative education, political, community development and environmental education.

\section{Non - Governmental Association for Literacy Support Services [ NOLGASS]}

Non - Governmental Organizations (NGOs) are service bodies that have been in existence before and after the creation of Nigeria (Biao and Adesina, 2006). These NGOs provide both emergency and enduring solutions to economic, political and social problems existing in Nigeria. Recent developments of the national NGOs include NOLGASS.

The Non - Governmental Association for Literacy Support Services (NOLGASS) which is an umbrella body for Non - Governmental Organizations (NGOs) supporting literacy delivery in Nigeria has the mission of all round literacy and development for all the people of the nation especially, at the grassroots level. It upholds the Right - Based Approach of Education for All (EFA).The service of NOLGASS both as an NGO and a Civil Society Organization (CSO) include, literacy delivery, lobbying and advocacy through Right - Based - Approach among Ministries, Agencies, Departments, National and State members. They share information and mobilize for campaign.

\section{Situation of Women in Nigeria}

Men and Women play salient roles in every society including Nigeria. The traditional Nigerian society was predominantly agrarian and socially organized around production. Gender discriminatory practices and exploitation through forced marriage, widowhood, and heritage rights was evident among the people. Although, literature also has it that, the acclaimed oppression of women in pre-colonial African State was not conclusively cosmopolitan. There were women like Iyalode of Ibadanland, Efunsetan Aniwura, Efunroye Tinubu, Funmilayo Ransome kuti, Ekpo, Queen Amina, Queen mother of Ashante in Ghana, the female heads of the Merde in Sierra 
Leone, the Edo in Benin, the Sagi and Sonya of Nupe in Nigeria who refused to be confined to traditionally assigned gender defined roles (Olayinka, 2013).

With colonianism gender function segregation was pronounced. There were distinctions between who function in the public and private domain Sudarkasa (2005) especially, because of western education. The education of the" Girl child" was not enhanced. The few that had formal education then, received education to function as good wives 'victorian education (Alese,2016a). There was also a lowering and in some cases total loss of means of livelihood for women as they could not cope with mechanized farming introduced by the westerners because of lack of skills (Olayinka, 2013).

Post colonialism and the present scene did not fair better. Although, there had been a few changes in the situation of women, the situation is yet to get to a significant level. Statistical data on global gender gaps in all significant spheres are proves of invisibility of women especially, in developing economies. The considerable discrepant gap in male and female education is a major factor affecting women. Recently, more women are being exposed to education at all levels but it will take time to bridge the gap. More so, since a high percentage of Nigerian men despite education are still patriarchal. The National Gender policy of 2006 which is expected to assist in addressing issues of inequality is only playing lip service to the issue.

According to Alese (2016) and Olayinka (2013) poverty is highly feminized. Nigerian women form sixty - five percent out of the seventy that live on less than US \$ 1 a day. The World Bank Gender Action plan aimed at economic empowerment of women is yet to be achieved (CEDAW NGO Coalition Shadow Report, 2008). Past governments have implemented several programmes aimed at economic empowerment of women which yielded tangential effect (Alese, 2010, 2012, 2014).The gender gap between Nigerian men and women in all spheres of life is still very large. For instance, the Global Gender Gap Report (GGGR) (2011) is enough evidence. Table I - III is self explanatory.

Table I: Economic Participation and Opportunity

\begin{tabular}{|l|l|l|l|l|l|l|}
\hline & Rank & Score & $\begin{array}{l}\text { Sample } \\
\text { average }\end{array}$ & Female & Male & $\begin{array}{l}\text { Female - } \\
\text { to - male } \\
\text { ratio }\end{array}$ \\
\hline $\begin{array}{l}\text { Economic } \\
\text { participation } \\
\text { and opportunity }\end{array}$ & 93 & 0.596 & 0.588 & - & - & - \\
\hline $\begin{array}{l}\text { Labour force } \\
\text { participation }\end{array}$ & 115 & 0.53 & 0.68 & 40 & 75 & 0.53 \\
\hline $\begin{array}{l}\text { Wage equality } \\
\text { for similar work }\end{array}$ & 14 & 0.77 & 0.65 & - & - & 0.77 \\
\hline
\end{tabular}




\begin{tabular}{|l|l|l|l|l|l|l|}
\hline $\begin{array}{l}\text { Estimated } \\
\text { earned income } \\
\text { (PPP US\$) }\end{array}$ & 112 & 0.41 & 0.52 & 1,283 & 3,119 & 0.41 \\
\hline $\begin{array}{l}\text { Legislators, } \\
\text { senior officials } \\
\text { and managers }\end{array}$ & - & - & 0.26 & - & - & - \\
\hline $\begin{array}{l}\text { Professional } \\
\text { and technical } \\
\text { workers }\end{array}$ & - & - & 0.64 & - & - & - \\
\hline
\end{tabular}

Table II: Educational Attainment

\begin{tabular}{|l|l|l|l|l|l|l|}
\hline & Rank & Score & $\begin{array}{l}\text { Sample } \\
\text { Average }\end{array}$ & Female & Male & $\begin{array}{l}\text { Female - } \\
\text { to - Male } \\
\text { ratio }\end{array}$ \\
\hline $\begin{array}{l}\text { Educational } \\
\text { Attainment }\end{array}$ & 125 & 0.809 & 0.928 & - & - & - \\
\hline Literacy rate & 122 & 0.69 & 0.86 & 50 & 72 & 0.69 \\
\hline $\begin{array}{l}\text { Enrolment in } \\
\text { primary } \\
\text { education }\end{array}$ & 125 & 0.90 & 0.98 & 58 & 64 & 0.90 \\
\hline $\begin{array}{l}\text { Enrolment in } \\
\text { secondary } \\
\text { education }\end{array}$ & 124 & 0.77 & 0.90 & 22 & 29 & 0.77 \\
\hline $\begin{array}{l}\text { Enrolment in } \\
\text { tertiary } \\
\text { education }\end{array}$ & 111 & 0.70 & 0.86 & 8 & 12 & 0.70 \\
\hline
\end{tabular}

Table III: Political Empowerment

\begin{tabular}{|l|l|l|l|l|l|l|}
\hline & Rank & Score & $\begin{array}{l}\text { Sample } \\
\text { average }\end{array}$ & Female & Male & $\begin{array}{l}\text { Female - } \\
\text { to - Male } \\
\text { ratio }\end{array}$ \\
\hline $\begin{array}{l}\text { Political } \\
\text { Empowerment }\end{array}$ & 121 & 0.038 & 0.185 & - & - & - \\
\hline $\begin{array}{l}\text { Women in } \\
\text { parliament }\end{array}$ & 124 & 0.04 & 0.22 & 4 & 96 & 0.04 \\
\hline $\begin{array}{l}\text { Women in } \\
\text { ministerial } \\
\text { positions }\end{array}$ & 90 & 0.11 & 0.18 & 10 & 90 & 0.11 \\
\hline $\begin{array}{l}\text { Years with } \\
\text { female head of } \\
\text { state (last 50) }\end{array}$ & 52 & 0.00 & 0.16 & 0 & 50 & 0.00 \\
\hline
\end{tabular}

Even the present Buhari administration reveals the prevalence of inequality. It is impressive the way women turn out during political rallies and campaign, women are used and dumped immediately aspirants had won political seats. According to Gberevbie and OvieSogue (2013) females between ages twenty and above constitute 50 -60 percent of the nation's 
population, yet their representation in decision- making has created a 'near exclusion'.

\section{Women Entrepreneurship}

Globally, the role of women in development cannot be over emphasized. The growth of economies of nations including the developed world is due to increasing participation and involvement of women in entrepreneurial activities. The Global Entrepreneurial Monitor (GEM, 2011) estimate 388 million new entrepreneurs in the world in 2011 and 163 million of these were women while 98 million run established businesses (GEM, 2012 Women’s Report).

Although, record for Nigerian women is not captured. It is estimated that women produce and process about eighty percent of the national food output (Alese, 2016a). Women in sub Sahara Africa have been widely involved in various agricultural productions especially, in areas of food crop farming, poultry and food processing. In their own informal way they have been manufacturers and industrialists, productive contributors to the economy but their access to knowledge, skills, resources and opportunities still remain rather low. Perhaps, the reason the International Labour Organization puts it succinctly that:

society's ability to accept new economic roles for women and the economy's ability to create decent jobs to accommodate them are the key prerequisites to improving labour market outcomes for women as well as economic development as a whole (ILO, 2008).

\section{Women's Creativity and Innovation.}

Women's creativity and innovation can be determined through their activities and that of women entrepreneurs. Both creativity and innovation are dependent on each other. It is impossible to develop a truly innovative organization if creativity is ignored. Similarly, without effective process in place to transform creative ideas into practical, real world, value added application; creativity cannot attain commercial value (Rigie and Harmeyer, 2009 in Alese, 2010). Internationally, women are very creative. They have a history of combining both creativity and innovation to effect positive change in the society though women in developing countries operate under low technology.

The creative and innovative abilities of women can be seen from the entrepreneurial skills they possess. They produce various meals as finished products from agricultural products like yam flour, cassava flour, corn meal, palm oil, smoked fish and the like. Ornaments from beads, adire from textile to mention a few. Creativity and innovation are keys to success in industries if adequately enhanced through technology. 


\section{Enhancing Women Skills through Lifelong Learning}

According to Sarumi, (2011) Adult education makes use of initial skills, changes wrong values and attitudes, updates knowledge and offer people lifelong learning through further training and its multidisciplinary component. As such, Adult Education and Lifelong learning assist in building the capacity and ability of individuals, institution and societies to perform functions and solve problems in a sustainable way.

It is important to note that although; women are endowed naturally to exhibit their Creative capacities, the sustainability especially in a knowledgebased world is incapacitated of which lifelong learning can assist in remediating. Lifelong learning is about acquiring and updating all kinds of abilities, interest, knowledge and qualification from pre-school years to postretirement. It promotes the development of knowledge and competencies to enable citizens adapt to the knowledge based society (Alese, 2016a). In essence, the potentials of lifelong learning to promote women's creativity is high. It is then left for NNCAE to partner and collaborate with necessary resource persons and institutions since Adult Education itself is multi and interdisciplinary.

\section{NNCAE, NOLGASS, Adult and Non formal Education through Lifelong Learning}

In order to take steps away from worldwide 'education crisis' that is said to allow for disparity between educational systems and the environment, Non - formal education was seen to be able to address issues of improved productivity, health, politics, education etc (Jegede, 2006). Lifelong learning is Non - formal in nature as it presents a wider view of learning than that enshrined in schooling and gives more scope to self development.

The NNCAE was more academic in its practice. However, this is not to say that NNCAE did not contribute to lifelong learning but the situation is that it was not done under a unified structure and strength that would have engender more successes. In essence, the efforts of both NOLGASS and NNCAE will be treated.

Adult Education is known to be rich, wide, comprehensive, multidisciplinary and interdisciplinary in scope as well as solves societal problems. In other words, apart from being academic, its practice enables a healthy town and gown relationship. According to Sarumi (2011) a renewed town and gown relationship could only be realized through adult and non formal education strategies and structures in the skills of community relationship, community development, active citizen participation, and mobilization strategies in programmes like community diagnosis felt needs, vocational education, and human sensitivity skills among others. Adult and Non - formal Education covers the activities of mankind. Sarumi (2011) 
affirmed that adult and Non - formal education provided expertise in the reduction of the nation's illiteracy rate, the reduction of HIV/AIDS and the revolution of Information Communication Technology among others.

Adult and Non - formal Education in Nigeria promotes continuing education opportunities. Workshops, seminars, training sessions and symposia are organized to impact on the people and the society through technical support from NNCAE and NOLGASS. Here people keep abreast of new skills where relevant up to date knowledge and information are passed.

\section{NNCAE, NOLGASS, Lifelong Learning and Women Entrepreneurship}

The contribution of NNCAE/NOLGASS to lifelong learning and women entrepreneurship will be treated from the perspective that at inception members of NNCAE are University academics and practitioners who belong to Non - Governmental Organization before the split. These are called Non - Governmental Association for Literacy Support Services (NOLGASS).

The NNCAE/NOLGASS enjoyed the support of the government, individuals and international organizations though in a token towards disseminating their services to the people and society. For instance, the Department of Adult Education, University of Ibadan and University of Port Harcourt had the UNESCO chair which is impacting positively to the life of the people. UNESCO is known to promote human development programmes especially, in developing countries. It does this through skill acquisition, training and retraining to foster University and community cooperatives.

The University of Ibadan through UNESCO has established vocational and skill acquisition centres for the community and members of the larger society to benefit from skills training such as tie and dye, soap making, stove - thread making, beading and the like (Sarumi, 2011). In collaboration with other donors, UNESCO has been able to support NNCAE in providing education holistically to the people, be it in women education, early childhood education, scontinuing education in the context of lifelong learning (Sarumi, 2011). At the University of Ibadan, the Centre for Literacy Training and Development Programme for Africa (CLTDPA) also organized computer training programmes for the people.

In collaboration with NNCAE, UNICEF is providing capacity building to rural dwellers through community vocation education and skill development programmes (Sarumi, 2011). Also, the International Foundation for Education and Self Help (IFESH), is assisting the University academia especially, University of Ibadan through the NGO called the University Village Association (UNIVA) to work in partnership with the people in the community to embark on projects that will improve the living standard of the people. A micro - credit scheme was attached to this project and it enabled 
participants to float small scale businesses. Mechanics, artisans, street children, and market women have benefited immensely from this arrangement.

The Ibadan Adult Education skills acquisition centre train and certificate people in vocation of their choice, computer technology and the internet (Sarumi, 2011).

\section{NNCAE and Functional Education.}

The provision of micro credit facilities is important to enhance the performance of these skills.

No doubt, functionality in education is the practical application of what is learnt as such, the education and training received by individuals should be such that meet the needs of the individual and the society through its practicability. Bamiro (2015) affirmed that there is an apparent disconnect between acquired skills of the product of the University system and the requirements of the Nigerian industry as the system still operate the curriculum laid down by the colonizers whereas the World Bank (2009) posits that tertiary education in general is fundamental to the construction of knowledge, economy and society in all nations. NNCAE need to correct this anomaly through Adult Education multidisciplinary components.

NNCAE has not collaborated with NOLGASS to enhance the skills of women from inception, the desire on their part to impact knowledge especially in the areas of crafts and local technology will be sustained with good collaboration. The situation where females are known for particular skills is not good enough. The percentage of women bricklayers, auto mechanics, painters, and the like should be improved upon. When women engage in more skillful and life skills they will be able to compete favourably with their male colleagues globally.

NNCAE must sensitize the society on the need for equity among the people from the beginning. Although, the policy of the nation states that there is equality of opportunities for everyone, this is more on paper than practice. Till now resources are not evenly distributed. Heritage rights still favour male children than the females whereas, empirical evidences support the fact that women are more prudent and pay back loans better than men. (Alese, 2010). NNCAE need to educate the society on the need for attitudinal change.

NNCAE should as a matter of urgency assist in improving the representation of women in decision - making by teaching skills on political education and sensitizing the people on the importance of this in the society. 


\section{Conclusion}

It was established in this study that Adult Education has potentials inherent in lifelong learning that could assist in reducing inequality, unemployment and underemployment which has resulted in weak democracy, instability of governance, poverty, crime and conflict of which women are the vulnerable in Nigeria. This also provides a conceptual framework for institutional analysis, linking the elements of the action (Adult and non-formal education, NNCAE, NOLGASS, situation of women in Nigeria ,women's creativity and innovation, and women entrepreneurship).

The traditional Nigeria society was predominantly agrarian and socially organized around production. Gender discriminatory practices and exploitation through forced marriage, widowhood, and heritage rights was evident traditionally and pronounced during colonization among the people. The gender gap between Nigerian men and women in all spheres of life is still very large.

The growth of economies of nations is due to increasing participation and involvement of women in developmental activities as listed above. In their own informal way, women have been manufacturers and industrialists, productive contributors to the economy and the society. When women engage in more skillful and life skills they will be able to compete favourably with their male colleagues globally.

NNCAE should as a matter of urgency assist and collaborate with relevant institutions in improving the lot of women by sensitizing and educating the people on the need for gender equity and enhanced skills that could stem unemployment, underemployment and gender inequity in the society. In doing these, NNCAE would have fulfilled its 'town gown' responsibility and redeemed its professional ethics of providing the right education to the citizenry at a dire need.

\section{References:}

Alese, O. (2010). Influence of the National Poverty Eradication Capacity Acquisition Programme on Women Empowerment in Oyo State, Nigeria. Ph.D Thesis Department of Adult Education, University of Ibadan, Ibadan, Nigeria.

Alese, O. (2013). Capacity Building and Skill Development among Female Entrepreneurs in Ido zone, Nigeria: Implications for Adult Education in S.O Odebode and M.M Umukoro (Eds) Gender and Higher Education in Africa: Emerging Issues. Proceedings of the First International and Interdisciplinary Conference March, 12 - 14. The Conference Centre, University of Ibadan, Ibadan Nigeria. 
Alese, O. (2016a). Entrepreneurship education and women graduates productivity in Ondo State Nigeria: available option in Lifelong skill approach. Proceedings of the international academic forum conference on Education, 2016, Dubai held at the International Festival City Event Centre February 26th - March 1st, 2016. www.iafor.org

Bamiro, O. A. (2015). The Nigerian University System and the Challenges of Catalysing and Nurturing Entrepreneurially - Gown Enterprises in the Nigerian Economy. A paper presented at the First International Conference of the Faculty of Education on Promoting Entrepreneurship Opportunities for Sustainable Development in the 21st Century. Nelson Mandela Hall Adekunle Ajasin University Akungba - Akoko, Nigeria 27 - 30 July, 2015. Bhola, H.S. (2000). Inventing a Future for Adult Education in Africa in the State of Adult and Continuing Education in Africa. Indabawa, S.., Oduaran, A.., Afrik, T.., and Walters, S. (Eds) Namibia. The Department of Adult and Non - formal Education, University of Namibia.

Coombs, P.H (1968). The world education crisis: A system analysis, London Oxford University Press.

Egunyomi, D.A (2015). Balancing Life Equation with Continuing Education. An Inaugural lecture delivered at the Trenchard Hall University of Ibadan, Ibadan, Nigeria. 02/07/2015

Gidado, T. (2006). Nigerian National Council for Adult Education in the Current Millenium: A rear-view mirror in Abiodun Okedara (ed.) Adult and Non-formal Education in Nigeria. Emerging Issues, NNCAE Annual conference, Ibadan, Nigeria, November 27- December 1, 2005.

Jegede, S. (2006). The compulsory, free Universal basic Education Act of 2004: The need for NNCAE to act in Abiodun Okedara (ed.) Adult and Nonformal Education in Nigeria. Emerging Issues, NNCAE Annual conference, Ibadan, Nigeria, November 27- December 1, 2005.

Nyerere, J.K. (2006). Adult Education and Development IIZ/DVV No 67

Olayinka, W. (2013). Gender inequality: African Feminist fiction reflecting scientific data in Stella Odebode and Mathew Umukoro (eds). Gender and Higher Education in Africa: emerging Issues. Proceedings of the first international and interdisciplinary conference centre, University of Ibadan, Ibadan March, 12-14,2014.

Sarumi, A. (2011). Contemporary Issues in Historical Foundations of Adult Education. Franco - Ola Printers Ibadan, Nigeria. 